\title{
Classification of Human Heart Abnormality using Time-frequency and Image Processing Technique
}

\author{
Fadzlul Rahimi Ahmad Bustami ${ }^{1}$, Mohd Hanif Md Saad ${ }^{1}$, Mohd Jailani Mohd Nor ${ }^{1}$, Bilkis Banu Aziz ${ }^{2}$ \\ ${ }^{1}$ MEMS-Automotive Research Group \\ Department of Mechanical and Materials Engineering \\ Universiti Kebangsaan Malaysia, \\ 43600 UKM Bangi, Selangor, \\ Malaysia \\ 2Pediatric Department, \\ Faculty of Medicine, \\ Universiti Kebangsaan Malaysia, \\ Bandar Tun Razak, Kuala Lumpur, \\ Malaysia \\ Received Date: $29^{\text {th }}$ August 2006 Accepted Date: $14^{\text {th }}$ February 2007
}

\begin{abstract}
This paper describes heart abnormalities classification procedures utilising features obtained from time-frequency spectogram of ECG heart and image processing techniques. Enhanced spatial features of time-frequency spectogram were extracted and fed into a forward chaining expert system and the corresponding abnormalities were identified. A confidence factor is calculated for every classification result indicating the degre of belief that the classification is true. It was observed that the classification method was able to give $100 \%$ correct classification based on features that was extracted from data sets which were included in the knowledge base and data sets which were not included in the knowledge base.
\end{abstract}

Keywords: Heart abnormalities classification, expert system, simultaneous time-frequency analysis.

\section{ABSTRAK}

Kertas ini menerangkan tentang prosedur klasifikasi jantung yang tidak normal yang didapati daripada spektrogram masa-frekuensi ECG jantung dan teknik-teknik pemprosesan imej. Ciri-ciri imej yang telah ditingkatkan daripada spektrogram masa-frekuensi diekstrak dan dimasukkan ke dalam rantaian ke hadapan sistem pakar dan seterusnya tahap ketidaknormalan jantung tersebut dikenal pasti. Faktor keyakinan yang dihitung pada setiap keputusan pengklasifikasian menunjukkan darjah keyakinan pada setiap proses tersebut. Daripada ujian, didapati kaedah klasifikasi ini mampu memberikan keputusan 100\% tepat terhadap set data yang cirinya diekstrak dan dimasukkan ke dalam pengkalan pengetahuan serta set data yang tidak dimasukkan ke dalam pengkalan pengetahuan.

Kata Kunci: Klasifikasi jantung tidak normal, sistem pakar, analisis masa-frekuensi serentak. 


\section{INTRODUCTION}

\section{Research Background}

It is generally known that by measuring and observing the electrocardiogram (ECG) of a human heart, a qualified medical practitioner would be able to determine the condition of the heart (whether the heart is normal or not normal). However, the process of deducing the condition of the human heart using time domain signals only is difficult due to the characteristics of the ECG plot in time domain.

The ECG of a normal heart rate consists of the $P$ wave, QRS complex, and T wave and repeats as shown in Figure 1.

\section{THEORY}

\section{Time and Frequency Domain Features}

Time domain ECG plots lack the signal intensity display of the frequency domain components. This is a great loss as frequency domain components contribute significantly in determining unique features of most engineering and scientific signals (Dripps 1997).

Consequently the frequency analysis of such signals via Fourier technique is fundamentally unsatisfactory since they are based upon modeling the signal as a linear combination of sinusoids extending throughout the duration of the signal. The Fourier analysis is good at

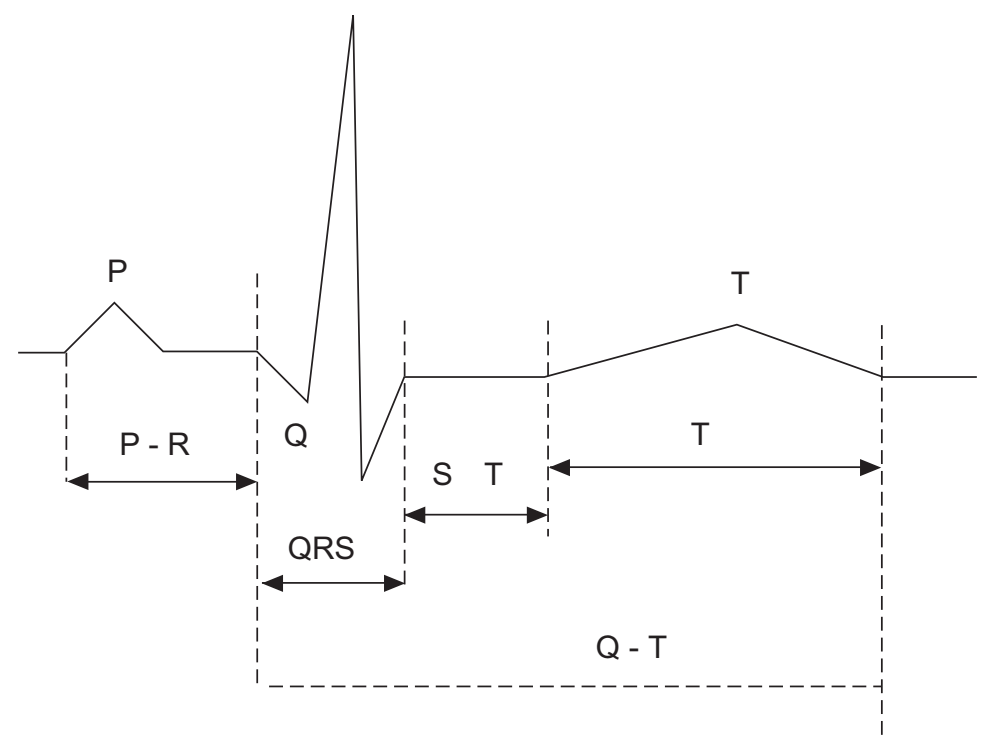

FIGURE 1. PQRST complex of an ECG pulse (Enderle et al. 2000)

The objective of this paper is to study and classify human heart abnormalities using information obtained from time-frequency spectrogram and image processing technique. determining frequencies presented (i.e. it provides good frequency discrimination), but poor at pinpointing when these frequencies occur (i.e. it has a poor time localization) (Crowe

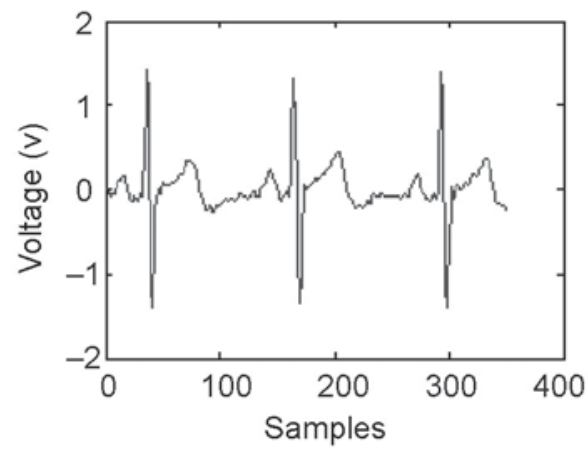

(a)

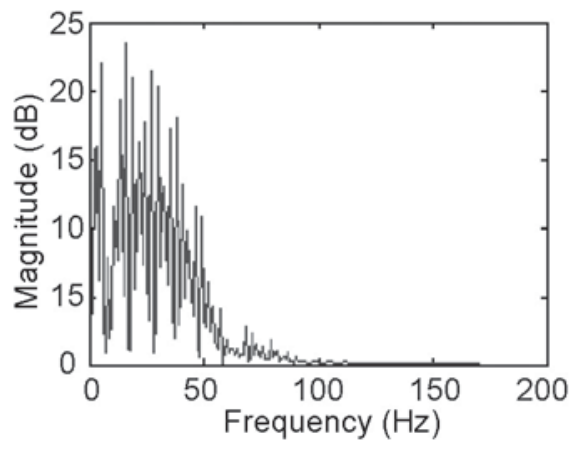

(b)

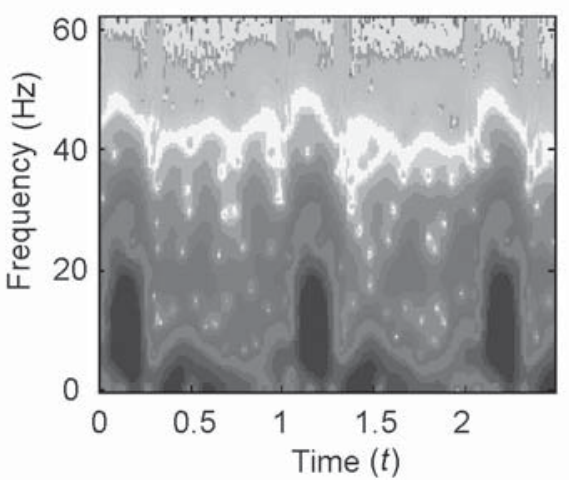

(c)

FIGURE 2. ECG Plots in (a) Time Domain, (b) Frequency Domain (c) Time-Frequency Domain 
1997) (Hlawatsch \& Boudreaux-Bartels 1992) (Haghighi-Mood \& Torry 1997).

Popular simultaneous time-frequency analysis techniques include the Wavelet Transform (Ikeda et al.1997) and the Short Time Fourier Transform. The example of time domain, frequency domain and simultaneous time-frequency domain display of ECG signals is shown in Figure 2.

\section{Short Time Fourier Transform (STFT)}

The short-time Fourier transform (STFT) is a linear time-frequency representation (TFR) used to present changes in the signal that vary with time. The Fourier transform does not explicitly show the time location of the frequency components, but some form of time location can be obtained by using a suitable pre-windowing (Hlawatsch \& Boudreaux-Bartels 1992). The STFT approach is to perform a Fourier Transform on a small section (window) of data at specific time from all signal data, thus mapping the signal into a twodimensional (2-D) function of time and frequency. The transform is described mathematically as

$$
X(\omega, a)=\int_{-\infty}^{\infty} x(t) g(t-a) e^{-j \omega t} d t
$$

where $g(t)$ may be defined as a simple box or pulse function. In discrete function, STFT is timedependent Fourier transform, of sequence $x[n]$ and defined by

$$
X_{\text {STFT }}\left(e^{j \omega}, n\right)=\sum_{m=-\infty}^{\infty} x[n-m] \omega[m] e^{-j \omega m}
$$

where $\omega[n]$ is a suitably chosen window sequence. It should be noted that the function of the window is to extract a finite length portion of the sequence $x[n]$ such that the spectral characteristics of the section extracted are approximately stationary over the duration of the window for practical purposes.
Note that if $\omega[n]=1$, the definition of STFT given in Equation (2) reduces to the convention discrete-time Fourier transform (DTFT) of $x[n]$. However, even though the DTFT of $x[n]$ exists under certain well-defined conditions, the windowed sequence in Equations (2) being finite in length ensures the existence of the STFT for any sequence $x[n]$.It should be noted also that, unlike the conventional DTFT, the STFT is a function of two variables: the integer variable time index $n$ and the continuous frequency variable $\omega$. It also follows from the definition of Equation (2), that $X_{\text {STFT }}\left(e^{j \omega}, n\right)$ is a periodic function of $\omega$ with a period $2 \pi$.

In this study, the Blackman window with a window size of 256 (50\% overlapping) discrete data out of a total of 512 discrete data was used. The Blackmann method of windowing was chosen because it gives minimum variation on spectrum shape and colour compared to other techniques. By observing the view of spectral peak, Blackman has the widest main lobe, but the lowest amplitude tails (Smith 1999). The discrete version of the Blackman window can be described by the equation below:

$$
\begin{aligned}
w[k+1] & =0.42-0.5 \cos \left(2 \pi \frac{k}{n-1}\right) \\
& +0.08 \cos \left(4 \pi \frac{k}{n-1}\right) \\
k & =0, \ldots, n-1
\end{aligned}
$$

\section{Linear Spatial Domain Filter}

One of the simplest linear, spatial image processing techniques used in machine vision is the convolution operation. The operation can be described as follows:

For any given planar image $P$ and a $3 \times 3$ element mask $G$ can be described by both equations (4) and (5) below:

$$
P=\left[\begin{array}{cccccccc}
g & g & g & g & g & g & g & g \\
g & g & g & g & g & g & g & g \\
g & g & P_{x_{n-1} y_{n-1}} & P_{x_{n} y_{n-1}} & P_{x_{n+1} y_{n-1}} & P_{x_{n+2} y_{n-1}} & g & g \\
g & g & P_{x_{n-1} y_{n}} & P_{x_{n} y_{n}} & P_{x_{n+1} y_{n}} & P_{x_{n+2} y_{n}} & g & g \\
g & g & P_{x_{n-1} y_{n+1}} & P_{x_{n} y_{n+1}} & P_{x_{n+1} y_{n+1}} & P_{x_{n+2} y_{n+1}} & g & g \\
g & g & P_{x_{n-1} y_{n+2}} & P_{x_{n} y_{n+2}} & P_{x_{n+1} y_{n+2}} & P_{x_{n+2} y_{n+2}} & g & g \\
g & g & P_{x_{n-1} y_{n+3}} & P_{x_{n} y_{n+3}} & P_{x_{n+1} y_{n+3}} & P_{x_{n+2} y_{n+3}} & g & g \\
g & g & g & g & g & g & g & g
\end{array}\right]
$$




$$
G=\left[\begin{array}{lll}
g_{11} & g_{12} & g_{13} \\
g_{21} & g_{22} & g_{23} \\
g_{31} & g_{32} & g_{33}
\end{array}\right]
$$

$$
\Delta P_{x}=G_{x}{ }^{*} P \text { and } \Delta P_{y}=G_{y}{ }^{*} P
$$

where

the convoluted image $P^{*}$ is given as:

$$
\begin{aligned}
P^{*}(x, y) & =\sum_{i=0}^{(m-1)} \sum_{j=0}^{(n-1)} G(i, j) \\
& P(x+i-1, y+j-1)
\end{aligned}
$$

where

$P$ : Planar image

$G$ : the mask

$x: \quad x$ axis coordinate for $P$

$y: \quad y$ axis coordinate for $P$

$i: x$ axis coordinate for $G$

$j: y$ axis coordinate for $G$

Different coefficient value will give different filter behaviour (Gonzales \& Woods 2002).

\section{Gaussian Filter}

The Gaussian filter smoothes a given image $P$ (Gonzales \& Woods 2002). It is made from the same structure in (4), (5), and (6) with specialized value of filter coefficient. The values varies according to the requirement and specification. A set of values is shown in equation (7):

$$
G=\left[\begin{array}{lll}
0.011 & 0.084 & 0.011 \\
0.084 & 0.619 & 0.084 \\
0.011 & 0.084 & 0.011
\end{array}\right]
$$

\section{Sobel Edge Detection}

In Sobel Edge detection, two operators were used, $G_{\mathrm{x}}$ and $G_{\mathrm{y}}$ to calculate approximations of the derivatives, one for horizontal changes, and one for vertical. The Sobel operators calculates the gradient of the image intensity at each point, giving the direction of the largest possible increase from light to dark and the rate of change in that direction. The result therefore shows how "abruptly" or "smoothly" the image changes at that point, and therefore how likely it is that part of the image represents an edge, as well as how that edge is likely to be oriented (Gonzales \& Woods 2002).

The operators follow the same structure as (6). If $P$ is defined as the source image, and $G_{x}$ and $G_{y}$ are the two operators described above, the latter are computed as:

$$
\begin{aligned}
& G_{x}=\left[\begin{array}{lll}
-1 & 0 & +1 \\
-2 & 0 & +2 \\
-1 & 0 & +1
\end{array}\right] \\
& \text { and } \\
& G_{y}=\left[\begin{array}{ccc}
+1 & +2 & +1 \\
0 & 0 & 0 \\
-1 & -2 & -1
\end{array}\right]
\end{aligned}
$$

At each point in the image, the resulting gradient approximations can be combined to give the gradient magnitude, using:

$$
\Delta P=\sqrt{\Delta P_{x}^{2}+\Delta P_{y}^{2}}
$$

Using this information, the gradient's direction is calculated as below:

$$
\Theta=\arctan \left(\frac{\Delta P_{y}}{\Delta P_{x}}\right)
$$

where, for example, $\Theta$ is 0 for a vertical edge which is darker on the left side.

\section{Non-Linear Spatial Domain Filter: Median Filter}

A median filter is a non-linear filter. In a median filter, the median value for the pixels in the processed window is used to replace the current pixel under processed (Gonzales \& Woods 2002). For example, a pixel (with the absolute value of $150)$ that is surrounded by 8 other pixels shown in equation (12) below is considered. Each pixels value is then arranged incrementally and the original pixel value in the middle is then replaced with a new value which is the value median of the arranged pixels. (Gonzales \&Woods 2002) (Fisher et al. 1994). Equation (12) describes how median filter is implemented.

$$
P=\left[\begin{array}{cccccccc}
g & g & g & g & g & g & g & g \\
g & g & g & g & g & g & g & g \\
g & g & 124 & 126 & 127 & g & g & g \\
g & g & 120 & 150 & 125 & g & g & g \\
g & g & 115 & 119 & 123 & g & g & g \\
g & g & g & g & g & g & g & g \\
g & g & g & g & g & g & g & g \\
g & g & g & g & g & g & g & g
\end{array}\right]_{(12)}
$$


Original Value : 150

Neighborhood values:115,119,120,123,124,125, $126,127,150$

Median Value : 124

\section{Pulse Counting From Binary Image}

The spectrogram obtained from the STFT operation is converted into grayscale and binary thresholded to produce a black and white only representation of the original STFT spectrogram.

At a selected frequency $\left(f_{\text {selected }}=45 \mathrm{~Hz}\right)$, the number of transitions made by pixel value are calculated. For example, if a line of pixel at any height is extracted, the following representation may be obtained:

$$
00011111111000000111111000
$$

From the example above, 4 transitions $\left(N_{T}\right)$ can be obtained. The pixels located in a pulse area
-1 , respectively, because the left figure has one connected component and one hole and the right component has one connected component but two holes (Gonzales \& Woods 2002).

\section{EXPERIMENTAL METHOD}

\section{Types Of Investigated Heart Abnormalities Investigated}

The types of heart abnormalities which were studied in this research are described in Table 1.

\section{Selection of Frequency Band}

The frequency band for the ECG signal was decided to be between $0.5 \mathrm{Hertz}(\mathrm{Hz})$ to $59 \mathrm{~Hz}$. Detailed signal analysis by previous researchers indicated that the P-wave and T-wave mainly consist of frequency components below 60 $\mathrm{Hz}$. The R-wave mainly consist of frequency components below $60 \mathrm{~Hz}$ but it also consists

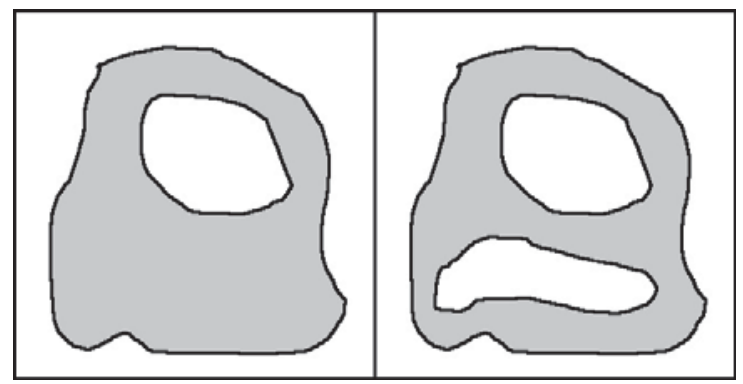

FIGURE 3. Regions with Euler number equal to 0 and -1

are indicated by 1 . Since the transition included from 0 to 1 and 1 to 0 , the number of total pulse is actually $N_{P}=N_{T} / 2$. In the above example, there are actually $4 / 2=2$ pulses detected. This method is by far not the most robust and precise pulse counting method, but it was observed throughout the study that the produced results were acceptable.

\section{Euler Number}

Euler Number is defined as the number of connected components. It is a topological property for region description. The number of holes $\mathrm{H}$ and connected components, $\mathrm{C}$ in an image can be used to define the Euler Number, E:

$$
E=C-H
$$

The regions are shown in Figure 3, for example, if the Euler numbers equal to 0 and of some frequency components above $60 \mathrm{~Hz}$. Using a band pass filter, the signal bandwidth was selected between 0.5 to $59 \mathrm{~Hz}$. Such a filter will effectively reduce $60 \mathrm{~Hz}$ noise (normally acquired through powerline), and have little effects on $\mathrm{P}$-wave and T-wave which finally produce some acceptable distortion on the R-wave. Cut-off frequency above $0.5 \mathrm{~Hz}$ was chosen to avoid the low-frequency noise due to respiration and electrode movement below $0.03 \mathrm{~Hz}$.

\section{Features Observed}

The features from the processed spectrogram image which was extracted and used for classification is described in Table 2.

\section{Classification Method}

The abnormalities were classified using a forward chaining Expert Systems and a corresponding 
TABLE 1. Type of Heart Abnormalities and Their Description

\begin{tabular}{|c|c|c|}
\hline$\#$ & Abnormality & Description \\
\hline 1 & Normal & Normal working heart. \\
\hline 2 & Atrial Fibrillation & $\begin{array}{l}\text { Atrial Fibrillation is an abnormality of the heart in which the atrial of heart } \\
\text { is not depolarized completely (activated).The P peak of the time domain } \\
\text { ECG is not very clear, but in time-frequency domain, the pulses are narrower } \\
\text { compared to the pulses from the normal heart. }\end{array}$ \\
\hline 3 & $\begin{array}{l}\text { Supraven } \\
\text { Arrhythm }\end{array}$ & $\begin{array}{l}\text { Hearts with Supraventricular Arrhythmia produces the maximum peak } \\
\text { frequency below } 50 \text { Hertz. }\end{array}$ \\
\hline 4 & $\begin{array}{l}\text { Ventricular } \\
\text { TachyArrhythmia }\end{array}$ & $\begin{array}{l}\text { In this kind of abnormality, the number of pulses in every period is } \\
\text { considerably bigger as compared to other kind of abnormalities and } \\
\text { normal heart. }\end{array}$ \\
\hline 5 & $\begin{array}{l}\text { Myocardial } \\
\text { Infarction }\end{array}$ & $\begin{array}{l}\text { This kind of abnormality generates pulses which are not firm compared } \\
\text { to the normal pulse due to the weakness of the heart to execute normal } \\
\text { heart activity. }\end{array}$ \\
\hline
\end{tabular}

TABLE 2. Features Observed

\begin{tabular}{|c|c|c|}
\hline \# & Features & Description \\
\hline 1 & Pulse Width & The width of individual pulses in the spectrogram \\
\hline 2 & Height & The height of individual pulses in the spectrogram \\
\hline 3 & Number of Pulse & The number of pulses recorded in 3.125 second in the spectrogram \\
\hline 4 & Intensity & The intensity of each pulses in the spectrogram \\
\hline 5 & $\begin{array}{l}\text { Euler Number for } \\
\text { individual pulse }\end{array}$ & The Euler Number calculated on individual pulse in the spectrogram \\
\hline 6 & $\begin{array}{l}\text { Euler Number for the } \\
\text { whole image }\end{array}$ & $\begin{array}{l}\text { The Euler Number calculated on the overall image of the } \\
\text { spectrogram }\end{array}$ \\
\hline 7 & $\begin{array}{l}\text { Euler Number for } \\
\text { individual pulse after } \\
\text { Sobel edge detection } \\
\text { operation }\end{array}$ & $\begin{array}{l}\text { The Euler Number calculated on the image of containing edges of a } \\
\text { single pulse. }\end{array}$ \\
\hline 8 & $\begin{array}{l}\text { Euler Number for the } \\
\text { whole image after } \\
\text { Sobel edge detection } \\
\text { operation }\end{array}$ & $\begin{array}{l}\text { The Euler Number calculated for the edges of the overall image of } \\
\text { the spectrogram. }\end{array}$ \\
\hline
\end{tabular}

overall certainty factor, $c f$, is calculated for every consequences. There were 25 rules in the Knowledge Base of the Expert System. Individual certainty factors for every consequence are empirically calculated from 40 available data. They represent the probability, $P_{j k}^{i}$ of the patient which diagnosed with abnormality- $i$ if feature- $j$ is equivalent to value- $k$. Since the same set of consequences is obtained as a result of the execution of two or more rules, the individual certainty factors of these rules is merged to give a combined certainty factor for a hypothesis. The knowledge base consists of the following rules:
Rule 1: IF PulseWidth is $P W_{1}$

THEN Abnormality is Normal $\left\{c f=c f_{11}\right\}$ Abnormality is AtrialFibrillation $\left\{c f=c f_{12}\right\}$

Abnormality is Supraventricular

Arrhythmia $\left\{\mathrm{cf}=\mathrm{Cf}_{13}\right\}$

Abnormality is Ventricular TachyArrhythmia $\left\{\mathrm{cf}=c f_{14}\right\}$

Abnormality is

Myocardiallnfarction

$\left\{c f=c f_{15}\right\}$

Rule 2: IF PulseWidth is $P W_{2}$

THEN Abnormality is Normal $\left\{c f=c f_{21}\right\}$ 
Abnormality is AtrialFibrillation

$\left\{c f=c f_{22}\right\}$

Abnormality is Supraventricular

Arrhythmia $\left\{c f=c f_{23}\right\}$

Abnormality is Ventricular

TachyArrhythmia $\left\{c f=c f_{24}\right\}$

Abnormality is

Myocardiallnfarction

$\left\{c f=c f_{25}\right\}$

Rule $j \times k$ : IF [features-j] is [ = value / within range of value of $k$ ]

THEN Abnormality is Normal $\{c f=$ $\left.c f_{j \times k, 1}\right\}$

Abnormality is AtrialFibrillation $\left\{c f=c f_{j \times k, 2}\right\}$

Abnormality is Supraventricular

Arrhythmia $\left\{c f=c f_{j \times k, 3}\right\}$
Abnormality is Ventricular TachyArrhythmia $\left\{c f=c f_{j \times k, 4}\right\}$

Abnormality is

Myocardiallnfarction

$\left\{c f=c f_{j \times k, 5}\right\}$

$c f_{j+1}^{i} \quad:$ the confidence in consequence- $i$ established by Rule- $((j+1) \times k)$

$\left|c f_{i}^{m}\right|$ and $\left|c f_{i+1}^{m}\right|:$ absolute magnitudes of $c f_{i}^{m}$ and $c f_{i+1}^{m}$, respectively.

: number of possible condition for feature-j

$P_{j k}^{i} \quad:$ probability of abnormality- $i$ when feature- $j$ has a value of $k$

TABLE 3. Classification Test Results

\begin{tabular}{llllllllllllll}
\hline $\begin{array}{l}\text { Data } \\
\text { Source }\end{array}$ & Abnormality & $\begin{array}{c}\text { Height } \\
(j=1)\end{array}$ & $\begin{array}{c}\text { Pulse } \\
(j=2)\end{array}$ & Width & Int. & $\begin{array}{c}\text { Euler } \\
\text { Ori }\end{array}$ & $\begin{array}{c}\text { Euler } \\
\text { Sobel }\end{array}$ & $\begin{array}{c}\text { Euler } \\
\text { All }\end{array}$ & $\begin{array}{c}\text { Euler } \\
\text { Sobel } \\
\text { All }\end{array}$ & CF & $\sqrt{ } / \mathbf{X}$ \\
\hline $\begin{array}{l}\text { Data to } \\
\text { Develop } \\
\text { the }\end{array}$ & $\begin{array}{l}\text { Atrial Fibrillational } \\
\text { System }\end{array}$ & 1.000 & 0.500 & 0.875 & 0.750 & 0.625 & 0.625 & 0.625 & 0.625 & 1.000 & $\sqrt{ }$ \\
& $\begin{array}{l}\text { Myocardial } \\
\text { Infarction }\end{array}$ & 0.675 & 1.000 & 0.625 & 0.125 & 0.500 & 0.500 & 0.375 & 0.250 & 0.960 & $\sqrt{ }$ \\
& $\begin{array}{l}\text { Supraventricular } \\
\text { Arrhythmia }\end{array}$ & 1.000 & 0.500 & 1.000 & 1.000 & 0.125 & 0.875 & 1.000 & 0.875 & 1.000 & $\sqrt{ }$ \\
& $\begin{array}{l}\text { Ventricular } \\
\text { Tachyarrhythmia }\end{array}$ & 0.250 & 1.000 & 0.125 & 1.000 & 0.750 & 0.250 & 1.000 & 0.625 & 0.910 & $\sqrt{ }$ \\
$\begin{array}{l}\text { Tested } \\
\text { Data }\end{array}$ & $\begin{array}{l}\text { Normal } \\
\text { Atrial Fibrillation }\end{array}$ & 1.000 & 0.500 & 0.875 & 0.750 & 0.625 & 0.625 & 0.250 & 0.625 & 1.000 & $\sqrt{ }$ \\
& $\begin{array}{l}\text { Myocardial } \\
\text { Infarction }\end{array}$ & 0.250 & 1.000 & 0.100 & 0.500 & 0.125 & 0.750 & 0.875 & 1.000 & 0.750 & 1.000 & $\sqrt{ }$ \\
& $\begin{array}{l}\text { Supraventricular } \\
\text { Arrhythmia }\end{array}$ & 1.000 & 0.500 & 1.000 & 1.000 & 0.125 & 0.875 & 1.000 & 0.875 & 1.000 & $\sqrt{ }$ \\
& $\begin{array}{l}\text { Ventricular } \\
\text { Tachyarrhythmia }\end{array}$ & 0.250 & 1.000 & 0.875 & 0.000 & 0.000 & 0.250 & 1.000 & 0.625 & 0.906 & $\sqrt{ }$ \\
\hline
\end{tabular}

To calculate the combined certainty factor for consequences- $i=1$ to 5 , which is the classified abnormalities, a modified version the following equation was used (Negnevitsky 2002):

$$
c f^{i *}\left(c f_{j}^{i}, c f_{j+1}^{i}\right)= \begin{cases}c f_{j}^{i}+c f_{j+1}^{i} \times\left(1-c f_{j}^{i}\right) & \text { if } c f_{j}^{i}>0 \text { and } c f_{j+1}^{i}>0 \\ \frac{c f_{j}^{i}+c f_{j+1}^{i}}{1-\min \left[\left|c f_{j}^{i}\right|,\left|c f_{j+1}^{i}\right|\right]} & \text { if } c f_{j}^{i}<0 \text { or } c f_{j+1}^{i}<0 \\ c f_{j}^{i}+c f_{j+1}^{i} \times\left(1+c f_{j}^{i}\right) & \text { if } c f_{j}^{i}<0 \text { and } c f_{j+1}^{i}<0\end{cases}
$$




$$
c f^{i}=c f^{i *} \times \frac{\sum_{j=1}^{j=n} P_{j k}^{i}}{n}, k=1,2, . ., q
$$

where:

$$
\begin{aligned}
c f_{j}^{i} \quad: & \text { the confidence in } \\
& \text { consequence- } i \text { established } \\
& \text { by Rule- }(j \times k)
\end{aligned}
$$

\section{RESULTS AND DISCUSSION}

The results for the tested classification are shown in Table 3.

The first five rows show the parameters and $c f$ of the classified abnormality for the data which was used to develop the knowledge base, where as the last five rows represent the classified abnormality for the data which was not used to develop the knowledge base, i.e., external data set. In both sets of data, the system was able to correctly classify the investigated abnormalities with $100 \%$ accuracy. The of for the classified

\section{REFERENCES}

Crowe, J.A. 1997. The wavelet transform and its application to biomedical signals.Time-Frequency Analysis of Biomedical Signals, IEE Colloquium on Year(Digest No. 1997/006), 29 Jan 1997:2/1-2/3.

Dripps, J.H. 1997. An introduction to time frequency methods applied to biomedical signals, TimeFrequency Analysis of Biomedical Signals, IEE Colloquium on Year(Digest No. 1997/006), 29 Jan 1997:5/1-5/6.

Enderle, J., Slanchard, S.\& Bronzio, J.2000. Introduction to Biomedical Engineering.San Diego:Academic Press.

Fisher, B., Perkins, S., Walker, A.\&Wolfart, E. 1994.Spatial filters median filter. (online) http://www.cee. hw.ac.uk/hipr/html/median.html (6 April 2006)

Gonzales, R.C. \& Woods, R.E. 2002. Digital image processing, $2^{\text {nd }}$ Ed. New Jersey: Prentice-Hall

Haghighi-Mood, A. \& Torry, J.N. 1997. Time Frequency Analysis of Systolic Murmurs. Time-Frequency Analysis of Biomedical Signals, IEE Colloquium on Year(Digest No. 1997/006), 29 Jan 1997:4/1-4/4

Hlawatsch.F, \& Boudreaux-Bartels, G. 1992.Linear and quadratic time-frequency signal representations. IEEE Signal Process Mag 9(2):21-67

Ikeda, K., Vaughn, B. \& Quint, S. 1997. Wavelet abnormality varies but the values were either close to or equal to 1.00 , which indicates strong belief in the result.

\section{CONCLUSION}

The detection results showed that the system functions very well and gives very good detection result (100\% accuracy). It is therefore concluded that that the objective of this research has been achieved. Future enhancement in this research includes the inclusion of more data in the knowledge base and of extraction. Further testing on larger test set is also planned in the near future to test the robustness and accuracy of this system.

\section{ACKNOWLEDGEMENT}

This work was supported by the Ministry of Science, Technology and Environment, Malaysia under the $8^{\text {th }}$ Malaysia Plan's IRPA 03-02-02-0016SR0003/07-02 Grant. decomposition of heart period data. Proceeding of The First Joint BMES/EMBS Conference Serving Humanity, Advancing Technology, Oct. 13-16: 99-110

Mitra, S.K., 1998, Digital signal processing, a computer based approach. Singapore: McGraw-Hill.

Negnevitsky, M. 2002. Artificial intelligence, a guide to intelligent systems. Essex:Pearson Education Ltd.

Smith, S.W. 1999. The Scientist and Engineer's Guide to Digital Signal Processing. ${ }^{\text {nd }}$ Ed. San Diego: California Technical Publishing.

Sprenger, Stephen M. Pitch-Scaling using the Fourier Transform. The DSP Dimension. (online) http:// www.dspdimension.com (6 April 2006)

Verhelst, W. \& Roelands, M. 1993, An overlap-add technique based on waveform similarity (WSOLA) for high quality time-scale modification of speech. Proc. IEEE ICASSP, Apr. 1993, pp. 554$-557$.

Wong, K. 2002. The Role of the Fourier Transform in Time-Scale Modification, Journal of Undergraduate Research 2(11), (online). http:// www.clas.ufl.edu/jur/200108/papers/paper_ wong.html (6 April 2006) 